\section{Journal of}

Gastroenterology
GE Port J Gastroenterol 2021;28:370-371

DOI: $10.1159 / 000511808$
Received: June 7, 2020

Accepted: August 15, 2020

Published online: December 4, 2020

\title{
Ball-Valve Syndrome, an Unusual Presentation of a GIST
}

\author{
Maria Margarida Carvalho ${ }^{\mathrm{a}}$ Ana Margarida Laranjo ${ }^{\mathrm{a}} \quad$ Andreia Rei $^{\mathrm{a}}$ \\ Lurdes Gonçalves $^{a}$ Carlos Quintana ${ }^{b}$ Isabel Medeiros ${ }^{a}$ \\ ${ }^{a}$ Gastroenterology Department, Hospital Espírito Santo - Évora, Évora, Portugal; ${ }^{b}$ Anatomopathology Department, \\ Hospital Espírito Santo - Évora, Évora, Portugal
}

\section{Keywords}

Gastrointestinal stromal tumor - Gastric outlet obstruction .

Ball-valve syndrome $\cdot$ Scarf-ring sign

\section{Síndrome de ball-valve, uma apresentação incomum de GIST}

\section{Palavras-Chave}

Tumor do estroma gastrointestinal · Obstrução ao esvaziamento gástrico $\cdot$ Síndrome de ball-valve $\cdot$ Sinal do cachecol

We present the case of an 87-year-old woman admitted to the emergency room due to persistent vomiting in the previous 4 days. She also complained of an intermittent abdominal pain and a weight loss of $10 \mathrm{~kg}$ with months of evolution. On physical examination, she had audible bowel sounds, painful palpation in the epigastrium without signs of peritoneal irritation. The laboratory panel showed only isolated neutrophilia, and the abdominal X-ray had no evidence of bowel distension.

karger@karger.com www.karger.com/pjg

Karger"

GOPEN ACCESS
C 2020 Sociedade Portuguesa de Gastrenterologia Published by S. Karger AG, Basel

This is an Open Access article licensed under the Creative Commons Attribution-NonCommercial-4.0 International License (CC BY-NC) (http://www.karger.com/Services/OpenAccessLicense), applicable to the online version of the article only. Usage and distribution for commercial purposes requires written permission.
The upper gastrointestinal endoscopy showed a distended gastric body and complete torsion of the gastric folds in the antropyloric region ("scarf-ring sign" shown in Fig. 1) causing obstruction to the passage of the endoscope.

After several attempts of aspiration, lavage and torque, it was possible to completely revert the torsion and reveal a bulky, semipediculated polypoid lesion with a large base of implantation on the anterior face of the distal body. Its surface was covered by congestive gastric mucosa with central erosion, suggestive of a submucosal lesion (Fig. $2,3)$.

Following the endoscopy, the patient tolerated progressive diet with no recurrence of vomiting. She was discharged and referred to a surgical consultation. The patient later underwent a laparoscopic atypical gastrectomy. The pathological specimen was compatible with a 4 $\times 3.2 \mathrm{~cm}$ gastrointestinal stromal tumor (GIST), with a low mitotic index (1/50 HPF), suggestive of a low-risk tumor by the modified National Institute of Health classification [1] (Fig. 4).

"Ball-valve syndrome" is a condition caused by intermittent prolapse through the pylorus of a gastric lesion, first described in 1946 by Hobbs and Cohen [2]. The clin-

Maria Margarida Água Morna Braga de Carvalho

Gastroenterology Department, Hospital Espírito Santo - Évora

Largo Senhor da Pobreza

PT-7000-811 Évora (Portugal)

mmargaridadecarvalho@gmail.com 
1

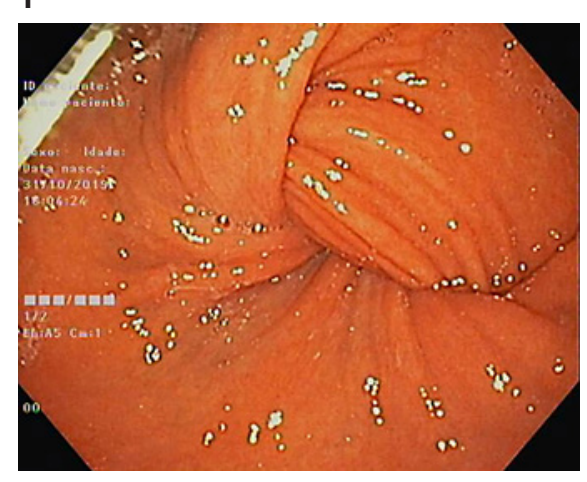

Fig. 1. Initial endoscopic image of complete torsion and invagination of gastric folds in the antropyloric region, compatible with the "scarf-ring sign."
2

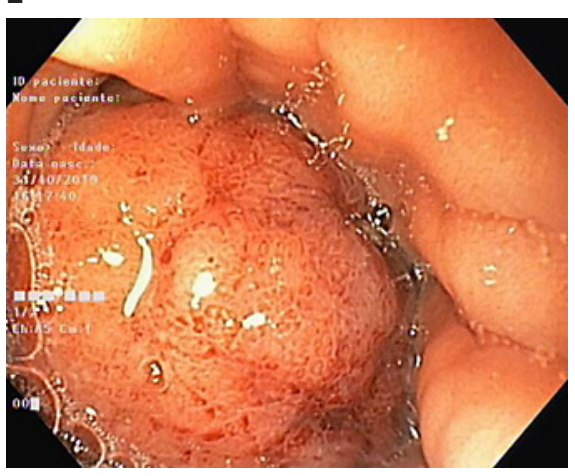

Fig. 2. After endoscopic resolution of gastric torsion, a bulky semipediculated polypoid lesion was observed.

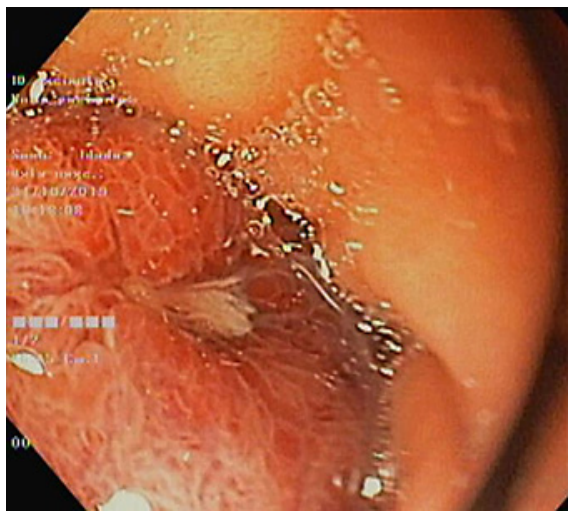

Fig. 3. Polypoid lesion with surface covered by congestive gastric mucosa with central erosion, suggestive of a submucosal lesion.

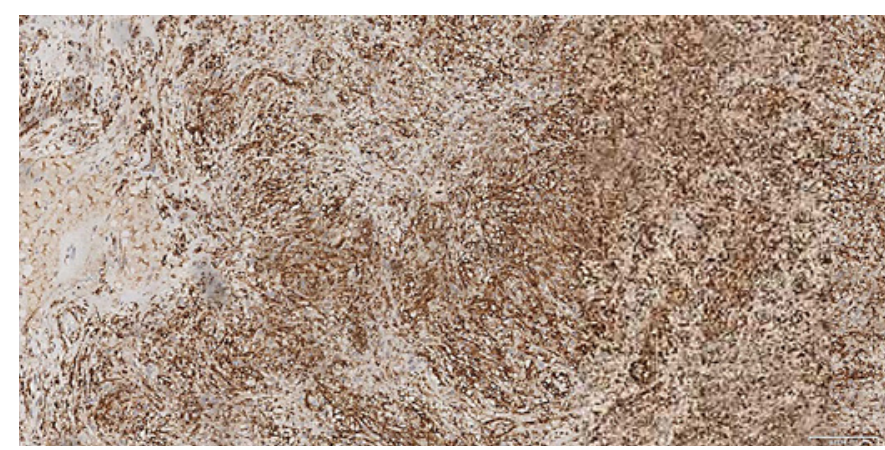

Fig. 4. Histology of the resected specimen with immunohistochemical study revealed CD117 positivity. Magnification $\times 20$.

ical manifestations are variable according to the degree of obstruction, ranging from abdominal discomfort or intermittent abdominal pain, nausea, vomiting and loss of appetite. The diagnosis is supported by imaging and/or endoscopic findings. The observation of a "scarf-ring sign" on endoscopy is a valuable clue to the diagnosis [3]. This is a rare GIST presentation, with only 18 cases previously reported in the literature [4].

\section{Statement of Ethics}

Informed consent was obtained from the patient for the case publication.

\section{Conflict of Interest Statement}

The authors have no conflicts of interest to declare.

\section{Funding Sources}

The authors have no funding sources to declare.

\section{Author Contributions}

Dr. Maria Margarida Carvalho wrote the paper. Dr. Carlos Quintana made and provided histological images. Dr. Ana Laranjo and Dr. Andreia Rei revised the paper. Dr. Lurdes Gonçalves and Dr. Isabel Medeiros revised the paper and approved the final version.

\section{References}

Ball-Valve Syndrome, an Unusual Presentation of a GIST
1 Joensuu H. Risk stratification of patients diagnosed with gastrointestinal stromal tumor. Hum Pathol. 2008 Oct;39(10):1411-9.

2 Hobbs WH, Cohen SE. Gastroduodenal invagination due to a submucous lipoma of the stomach. Am J Surg. 1946 Apr;71(4):505-18.

3 Yazumi S, Nakase H, Matsushima Y, Chiba T, Shirahase I, Yoshizaki S, et al. The "scarf-ring sign" of ball valve syndrome. Gastrointest Endosc. 2002 Apr;55(4):560.

4 Đokić M, Novak J, Petrič M, Ranković B, Štabuc M, Trotovšek B. Case report and literature review: patient with gastroduodenal intussusception due to the gastrointestinal stromal tumor of the lesser curvature of the gastric body. BMC Surg. 2019 Oct;19(1):158. 